\title{
Research on the Dynamic Response of Frame Structure under the Explosion Load of Acetylene-Air Mixture
}

\section{Jun Gao}

Xi'an University of Architecture and Technology

Xin Zhang ( $\square$ civil_xinzhang@163.com)

Yanshan University

Jiheng Liu

Xi'an University of Architecture and Technology

\section{Research Article}

Keywords: Time history analysis, dynamic response, SAP2000 finite element simulation, RC frame structure, explosion load

Posted Date: November 1st, 2021

DOI: https://doi.org/10.21203/rs.3.rs-1011302/v1

License: (c) (i) This work is licensed under a Creative Commons Attribution 4.0 International License. Read Full License 


\title{
Research on the Dynamic Response of Frame Structure under the Explosion Load of Acetylene-Air Mixture
}

\author{
Jun Gao ${ }^{1,2}$; Xin Zhang ${ }^{* 3}$; Jiheng Liu ${ }^{1,2}$ \\ (1. College of Civil Engineering, Xi'an University of Architecture and Technology, Xi' an 710055, China \\ 2. Key Lab of Structural Engineering and Earthquake Resistance, Ministry of Education (XAUA T), Xi'an 710055, China; \\ 3. College of Civil Engineering, Yanshan University, Qinhuangdao 066000, China )
}

\begin{abstract}
Explosion is the act of generating huge energy in an instant and spreading rapidly around it. Due to the suddenness, fast propagation speed and high peak load of explosions, compared with other natural disasters, the damage it brings to humans is more significant and difficult to prevent. Among them, the explosion of acetylene-air mixture is the most typical explosion problem. This paper uses SAP2000 finite element software to perform a fine simulation of actual explosion events, studies the effect of the explosion of acetylene-air mixture on the frame structure column, and discusses the displacement and acceleration changes of various components. Research shows that the use of the principle of linear assumption of explosive load can effectively simulate the actual explosion situation. The structural damage and deformation caused by the explosive load have locality and weak transmission. When the peak of the explosion load is larger, the structure deformation is greater, and the impact of the explosion load on the structure is isotropic.
\end{abstract}

Key words: Time history analysis, dynamic response, SAP2000 finite element simulation, RC frame structure, explosion load

\section{Introduction}

With the rapid development of the chemical industry, gas explosion accidents have occurred from time to time, which not only caused heavy casualties, but also caused huge property losses. Explosive loads are different from common natural disasters in that they are sudden, violent, and difficult to resist by humans (Han and Chen 2008; Kobiera et al. 2007). According to statistics,

\footnotetext{
*Correspondence to: civil_xinzhang@163.com
} 
terrorist bombings accounted for more than $57.58 \%$ of the terrorist attacks on the world, causing great casualties and going against the maintenance of a stable and peaceful international environment. Public facilities have become the main targets of terrorist attacks, and the impact load caused by the explosion is one of the important factors affecting the safety of building structures (Molkov et al. 2000). Therefore, the anti-riot capability of the building structure has become an indispensable indicator for the evaluation of the safety and reliability of the structure (Mander et al. 1988).

In addition to terrorist attacks, civil buildings are also often exposed to explosions. In September 2013, a gas explosion accident occurred in the entire first-floor workshop of a science and technology company in Xi'an, Shaanxi Province, China, causing serious damage to the beams, columns and floor slabs of the first and second floors, and some walls collapsed seriously, as shown in Fig. 1.

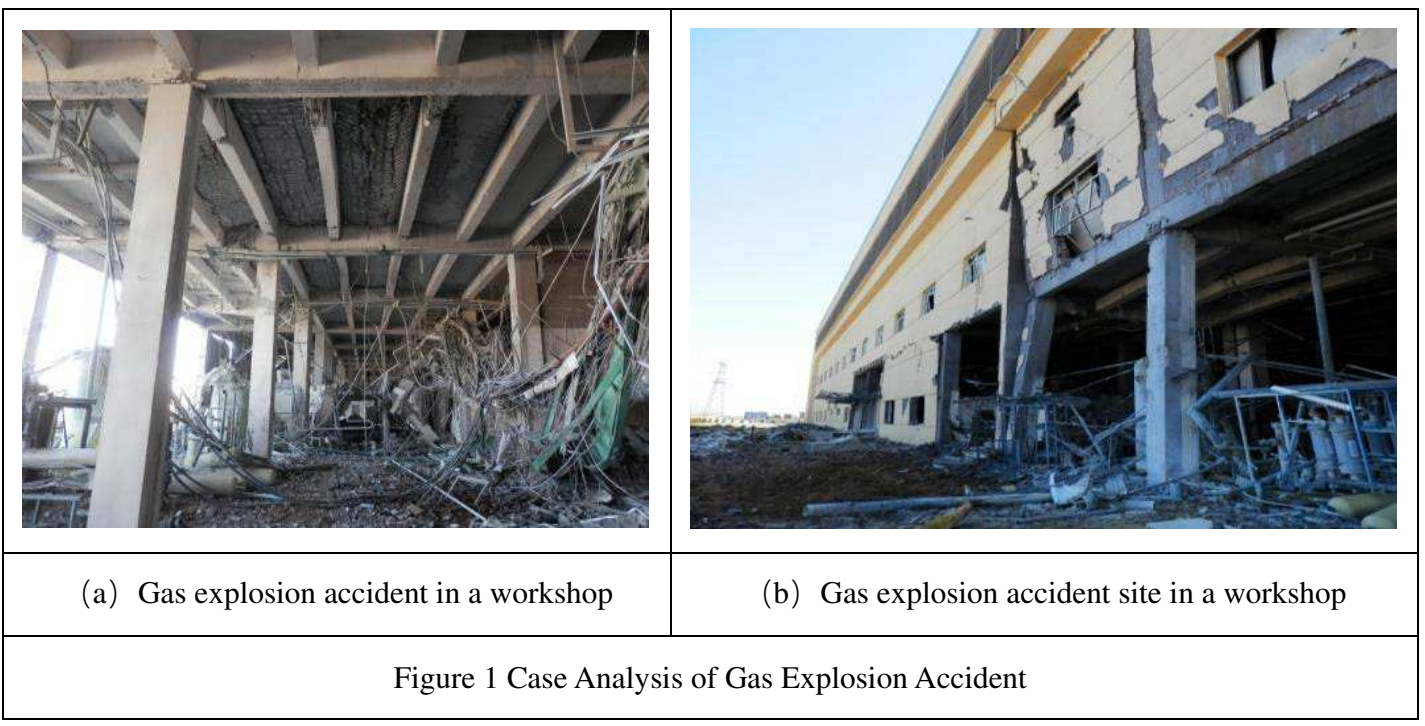

Explosive loads are different from natural disasters such as earthquakes, tsunamis, and typhoons. Explosive loads are sudden, violent, and usually beyond people's normal ability to withstand disasters (Ambrosini et al. 2005). Once an explosion occurs in a building structure, it will cause irreversible damage to the building structure itself. Explosive loads have obvious dynamic nonlinear effects on structures and structural systems. Explosive loads have obvious characteristics of the distribution, violent, and suddenness. Especially in the past century, international and domestic terrorist attacks have become more frequent, which makes people put forward new requirements for the anti-riot capability of building structures. Whether it is a military or civil industry, it is very concerned about the plastic response of building structures after being subjected to explosive loads. 
Ability to evaluate the ability of building structures to withstand explosive loads (Mander et al. 1988). Therefore, it is meaningful and necessary to study the dynamic response of the structure under explosive load.

The problem of the safety and reliability of the building structure after being subjected to the explosion load and the explosion load is the core issue in the study of the impact of the explosion load on the building structure. The reliability of the building structure is the ability of the building structure to withstand loads and resist various adverse conditions during the normal service life of the building to ensure the safe and normal use of the building (Kobiera et al. 2007). Due to the particularity of the explosive load, after the structure is subjected to the explosive load, it will deform much larger than normal, resulting in different degrees of damage. In this case, we have to evaluate the safety and reliability of the building structure to see whether the building structure can perform the specified functions and the probability value to ensure the safety and reliability (Krauthammer and Asce 1984; Krauthammer et al. 1986).

In recent years, studying the nonlinear dynamic response of building structures under strong explosive loads and evaluating the bearing capacity and safety and reliability of building structures against explosive loads has become a matter of great concern in the fields of important buildings, bridge engineering, and high-speed transportation (Molkov et al. 1999; . Ships are generally maintained by structural members such as plates and shells. They are simple to manufacture and light in weight, and are widely used in the engineering field. Ship structures are very susceptible to underwater or door-to-door explosions and impacts during wars or terrorist attacks, causing damage or even capsizing of the ship's structure (Oswald 2005).

The research on explosion-proof and anti-blast loads mainly focuses on military engineering, such as military bridges, air-raid shelters, and so on. Due to the rapid development of industry, frequent explosions in chemical companies, as well as people's negligence and improper operation in production and life, will lead to some accidental explosions. Therefore, more and more researchers have begun to conduct research on buildings subjected to explosive loads, involving the explosive load encountered by the building structure, the characteristics of structural damage, the dynamic response after the explosive load, etc., and have obtained relatively rich research results.

However, there are few studies on the influence of the concrete frame by the gas explosion load, because the explosion load related test is more difficult to do, and it is not easy to meet the test 
conditions. Domestic research on explosive loads mainly focuses on finite element simulation, and lacks the support of specific tests and engineering examples. Due to the limitations of test conditions, research objects, and objective conditions, many related issues about explosive loads are not yet clear, such as the vulnerability of frame structures under explosive loads. The propagation mechanism and energy dissipation law of shock waves in frame structure beams, slabs, columns and infill walls; the continuous collapse mechanism of the structure after being subjected to explosive loads are all issues that must be faced in the field of explosion.

This paper uses the finite element analysis software SAP2000 to establish the relevant finite element model of the structure subjected to explosive load, and imposes the explosive load on the finite element model. Carry out data analysis, study the displacement of beams, plates, columns, acceleration dynamic response, and plastic hinges analysis of structural members after the structure is subjected to explosive loads. Provide a certain reference basis for gas explosion disaster mitigation countermeasures and structural anti-riot design.

\section{Numerical simulation of frame structure under acetylene-mixed gas explosion load}

\section{Project overview}

The 3\# transfer station of the Acetylene Branch of a chemical branch of a chemical group company in Shaanxi Province, China was built in 2010. The building plan is basically rectangular, $52 \mathrm{~m}$ long from east to west, and $12 \mathrm{~m}$ wide from north to south. There are a total of 8 column distances between the east-west direction, each of which is $6 \mathrm{~m}$, and a total of 2 column distances from the north-south direction, with the column distances being $6.5 \mathrm{~m}$ and $6 \mathrm{~m}$ respectively. The elevations of each floor are 7.28m, 15.78 and 20.5m, respectively. 3-B 3-C axis/3-1 3-7 axis are equipped with calcium carbide silo within each column distance range. The top elevation of the silo is $15.78 \mathrm{~m}$, the bottom elevation of the silo wall is $12.7 \mathrm{~m}$, and the silo wall is equipped with a wearresistant layer.

The transfer station adopts a cast-in-place reinforced concrete frame structure, and each layer of 
frame beams and frame columns adopt rectangular cross-sections. The cross-sectional dimensions of the frame columns on each floor are $800 \mathrm{~mm} \times 800 \mathrm{~mm}$, and the column distances between the first and second floors of the 3-B axis and the 3-C axis are all set with herringbone concrete supports. The wall of the calcium carbide silo is made of cast-in-place reinforced concrete. The wall thickness of the silo is $300 \mathrm{~mm}$. The upper and lower parts of the wall are $700 \mathrm{~mm}$ dark beams. The cross section of the junction between the end of the silo wall and the concrete column is enlarged. The hopper of the silo adopts a steel hopper, which is connected with a pre-embedded angle steel on the wall of the silo. The angle steel of the original design is connected with the concrete through two steel bars with a diameter of $14 \mathrm{~mm}$ and a distance of $100 \mathrm{~mm}$.

\section{The disaster situation of the project}

At around 21:45 on July 11, 2016, the DCS operator of the Acetylene Branch of the Chemical Branch used the 3\# buffer silo to feed the $8 \#$ coarse silo in the fourth zone of the second phase. At 22:00, the DCS operator found that the $8 \#$ coarse silo contained $0.47 \%$ of acetylene and entered the yellow zone of key process parameters, and immediately stopped feeding the 8\# coarse silo. From 22:47 to 23:16, the $3 \#$ buffer silo has been always in the state of material preparation (the material level rises from 0 to $53.15 \%$ ), and the DCS operator starts the 3\# buffer silo feeder to the second at 23:17:08. Three-zone feeding occurred during the period, and the $3 \#$ buffer silo immediately exploded at 23:18:18. According to the data collection and sampling analysis of the accident site, the direct cause of the accident was that the $3 \#$ buffer silo added part of the calcium carbide powder wet material. The moisture in the calcium carbide powder wet material reacted with the calcium carbide particles and released a large amount of acetylene gas. At the same time, the pressure of the nitrogen pipeline is low, and some nitrogen pipelines of the silo are not connected with the buffer silo during the construction process, which leads to an explosion accident.

The accident mainly caused damage to the colored steel and windows on the south and north sides of the $3 \#$ transfer station plant, damage to the $3 \#$ belt bracket and cable tray, and the $3 \#$ buffer silo ruptured. 
The location of the explosion silo is shown in Fig. 2 in the middle of the plant. After the explosion, the relevant experts and the investigation team entered the site in time to observe and appraise the damaged structure in time, and concluded that the acetylene gas explosion had an effect on the structure. The main damage is as follows:

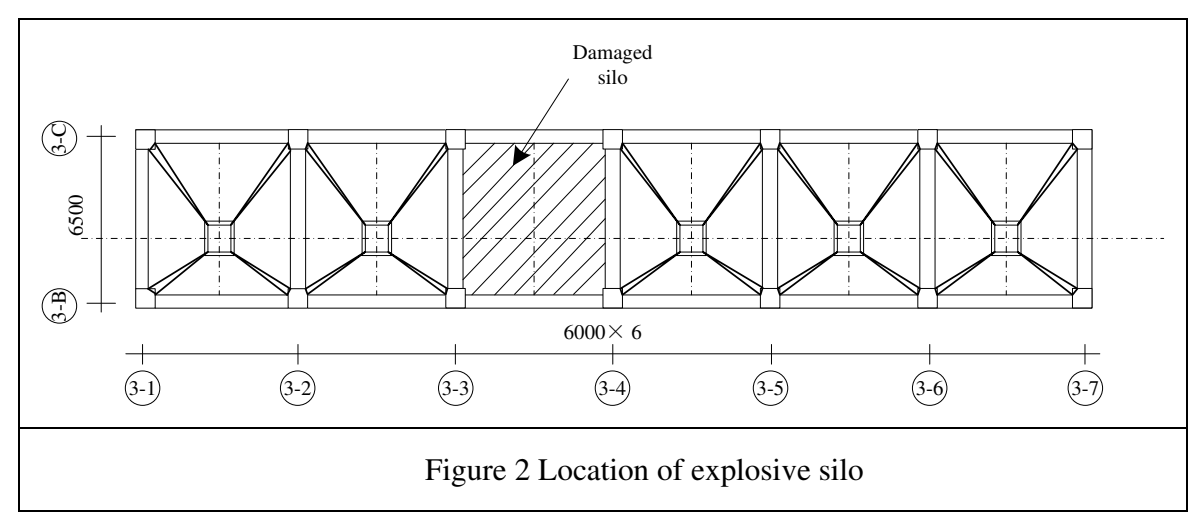

(1) The concrete beams and slabs on the top of the silo (15.78m elevation 3-B 3-C axis/3-3 3-4 axis) have been severely deformed, cracked and peeled due to the impact load of the explosion. From Fig.3 (a), it can be seen that the surface of the top area of the silo is the most damaged. Only vertical and horizontal steel and concrete beams are seen on the top of the silo. Almost the entire concrete slab is shattered by the acetylene explosion load. From Fig.3 (b), it can be seen that under the impact of the explosion load, the structural concrete beams are also seriously damaged. The two ends of the concrete beam have been separated from the surrounding structure, and the concrete of part of the concrete beam has seriously fallen off, and the steel frame can be clearly seen. Fig.3 (c) and (d) show the damage to the beam on the top of the silo. It can be seen that the concrete of the beam at this stage has completely withdrawn from work and replaced by steel bars. The longitudinal bars of the beam are severely bent and have reached yield and even some beams fall off as a whole. Fig.3 (e) and (f) show that the explosion load damages the plates and beams in the top area of the adjacent silo. It can be seen from the figure that the slab concrete in the top area of the adjacent silo has been shattered in a large area, and the steel bars are severely bent. 


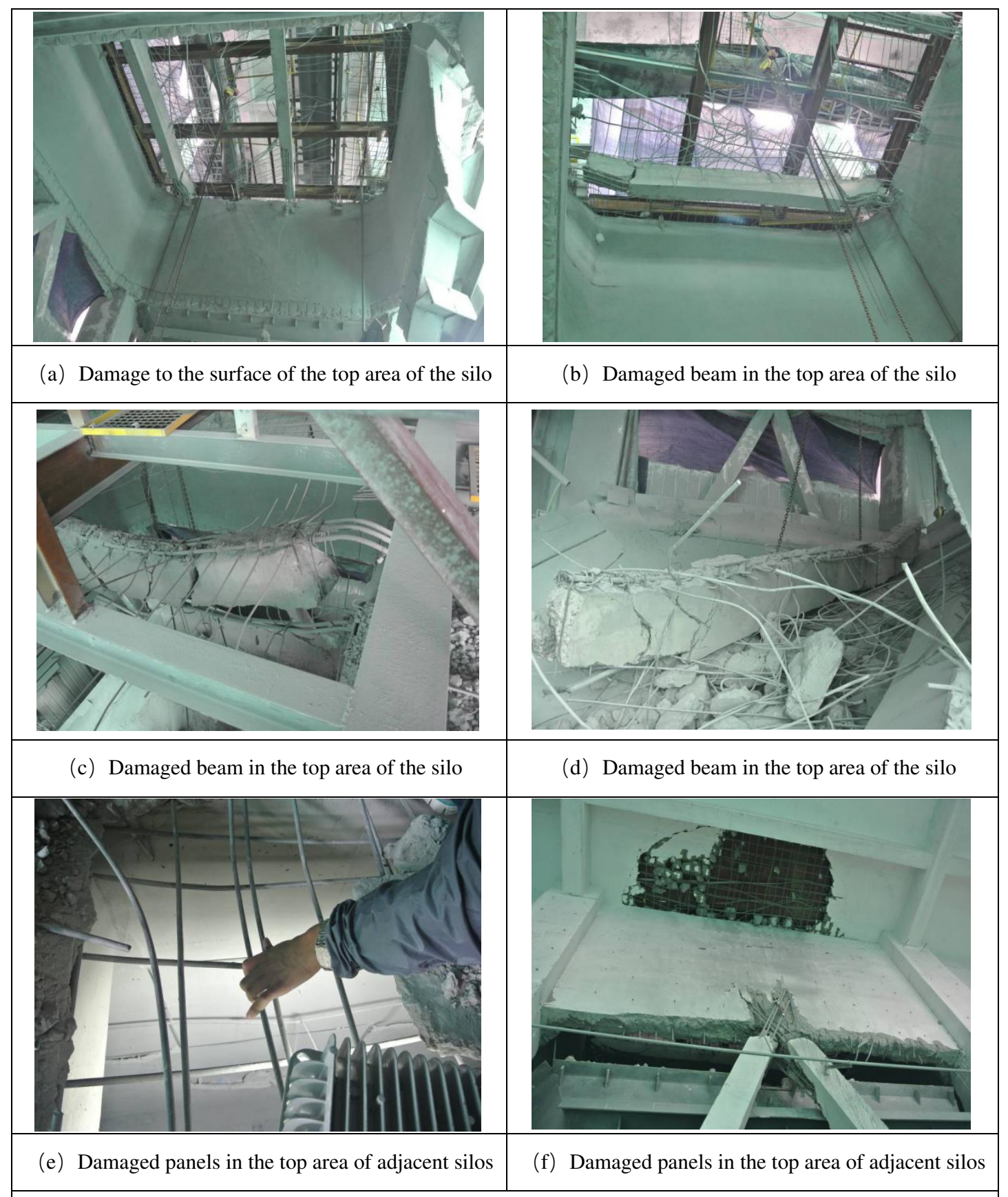

Figure 3 Damage to structural beams and slabs caused by explosive loads

(2) The falling of the steel funnels impacts the concrete support of the 3-B axis, causing the impacted part on the top to flash out of the plane, the concrete is loose and falling off, and the steel bars are exposed. As shown in Fig.4 (a), due to the external flashover of the support, local concrete cracks on the silo wall at the anchorage position of the support steel bar, the column plane is inclined out of the plane, the concrete spalls in a large area, and the steel bar leaks seriously. In contrast, the concrete on the other three sides of the silo wall was slightly damaged, and the wear-resistant layer material was partially peeled off. At the same time, the embedded steel bars of the funnel were cut 
as shown in Fig.4 (b) and (c).

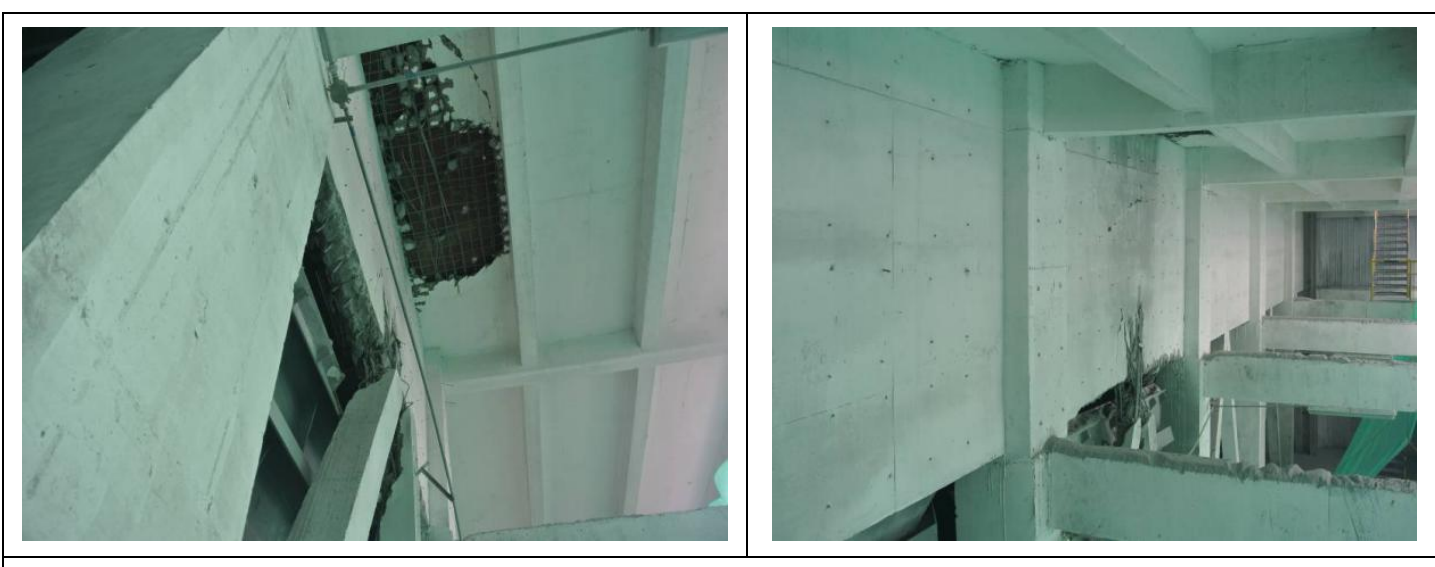

(a) The damage of the support and warehouse wall

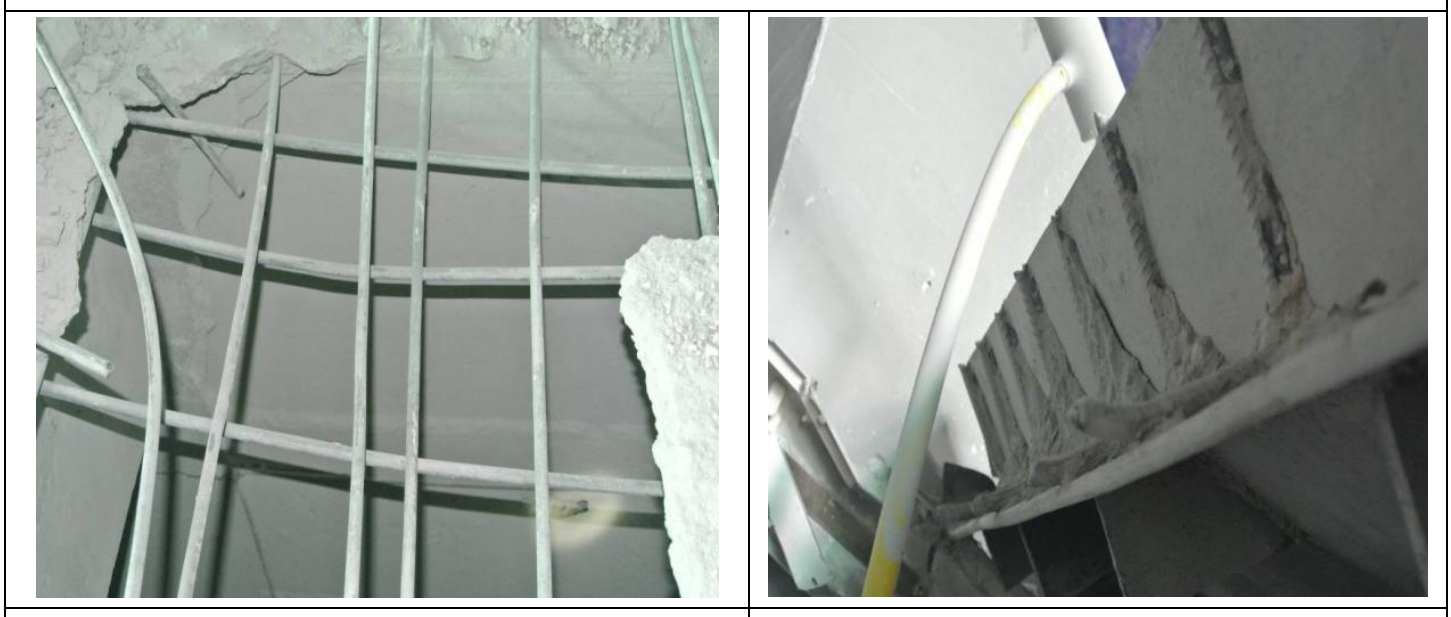

(b) Shedding of wear-resistant material on warehouse

wall

(c) Funnel embedded steel bar cutting

Figure 4 Damage of acetylene explosion load to concrete silo wall

(3) It can be seen from Fig.5 (a) and (b) that the steel funnel is impacted, the anchoring steel bars are cut off as a whole, and the welds are pulled off. The measured steel bar spacing on site is $200 \mathrm{~mm}$. The connection welds between the steel bars and the angle steel adopt intermittent welding. The seam is severely pulled off, and the steel bar is pulled out in a large area. The acetylene explosion load also has a great impact on the maintenance wall surface of the structure. As shown in Fig.5 (c) and (d), the maintenance wall surface of the structure has already produced a large deformation, which seriously affects the normal use of the structure. It is very necessary to carry out inspection, repair and reinforcement. 


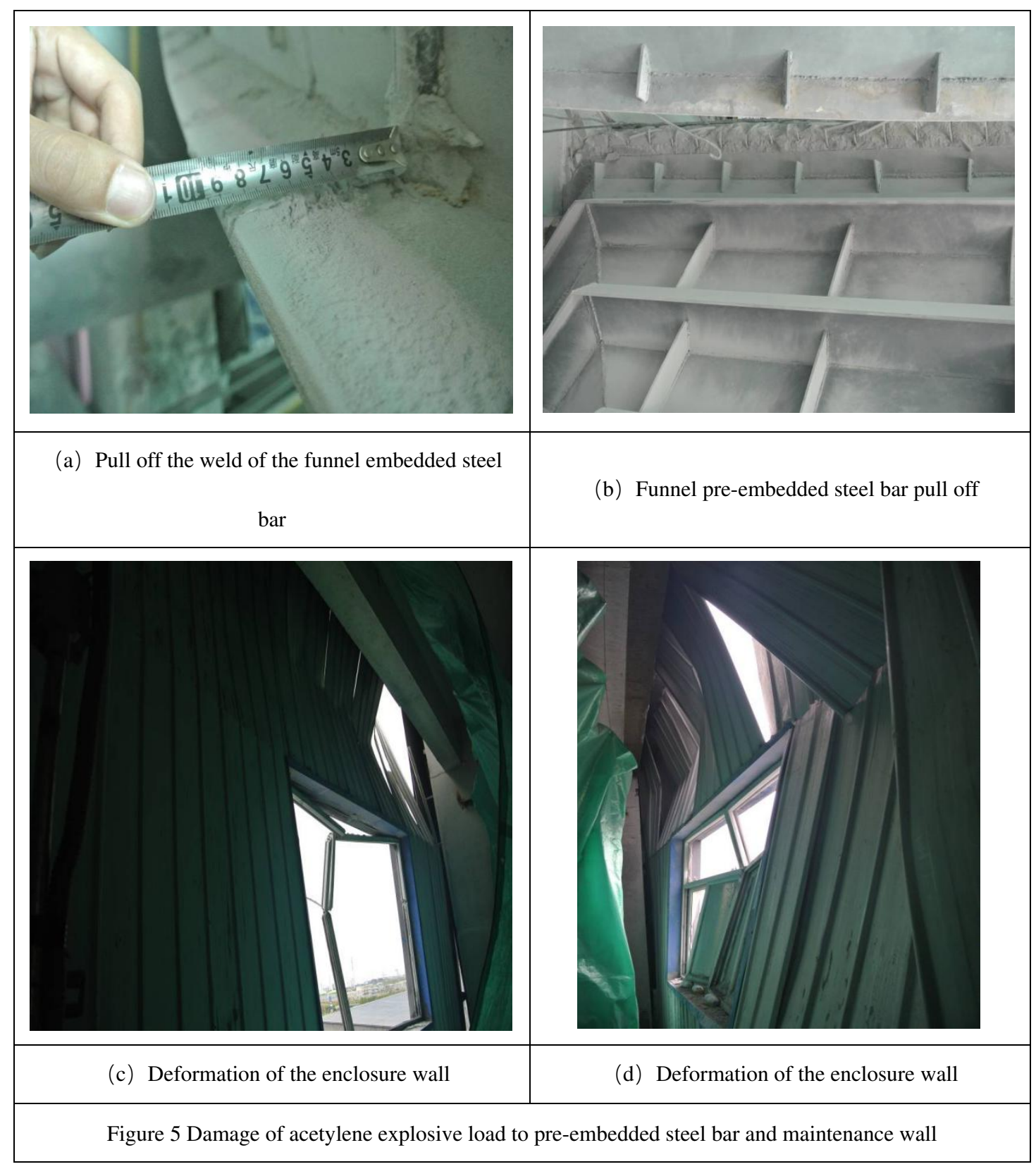

\section{Determination of acetylene-mixed gas explosion load}

The nature of the explosive load of acetylene-mixed gas

Generally, the pressure value during a gas explosion is $25-50 \mathrm{KPa}$. Only when there are multiple factors, the pressure can reach more than $100 \mathrm{KPa}$ (Molkov et al. 2000). When the structure is completely enclosed, the maximum explosion pressure produced by the acetylene-mixed gas can reach $700 \mathrm{KPa}$. The pressure rise time of acetylene-mixed gas is usually $100-300 \mathrm{~ms}$. Its main 
characteristics are slow pressure rise and lower peak pressure. When the explosive load acts on all surfaces of the structure, the pressure relief is often broken through doors, windows, partition walls, etc. The peak load pressure that actually occurs in an explosion accident is generally only $5-50 \mathrm{KPa}$ (Molkov et al. 1999; Murray et al. 2000; Kumar et al. 1989).

\section{Selection of acetylene-mixed gas explosion load curve}

Explosions can be divided into physical explosions, chemical explosions, and gas explosions according to different conditions. Among them, acetylene-air mixed gas explosions belong to gas explosions, and the explosion load time history curve is shown in the Fig.6. It can be seen from the curve that gas explosion is milder than a physical explosion and chemical explosion, and its pressure rise time is the slowest, generally about $0.1 \mathrm{~s}-0.3 \mathrm{~s}$, and there are almost no negative pressure section. The acetylene-mixed gas explosion in this paper should use the gas explosion load time history curve.

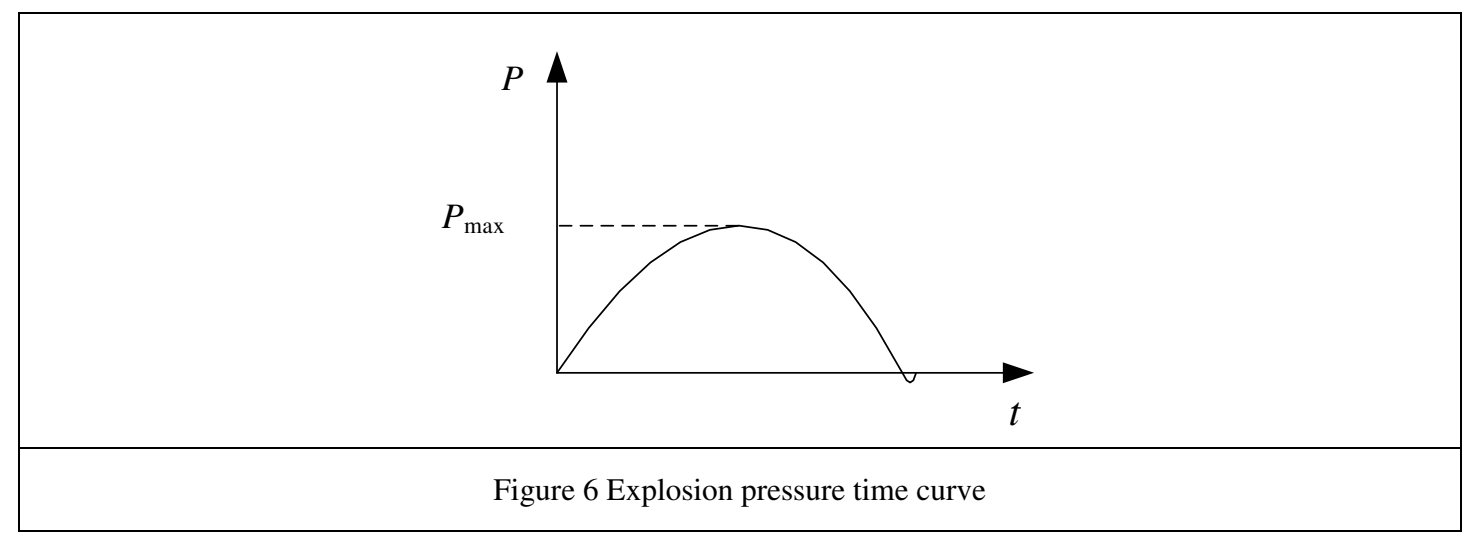

From the gas explosion load time history curve, it can be seen that the energy of the acetyleneair mixture explosion basically occurs in the positive part of the curve. Therefore, when simulating the gas explosion load, for simplicity, the explosion load is expressed as a uniformly distributed load over time. The specific curve is shown in Fig. 7, where is the peak action time, the release time, and the maximum load intensity. 


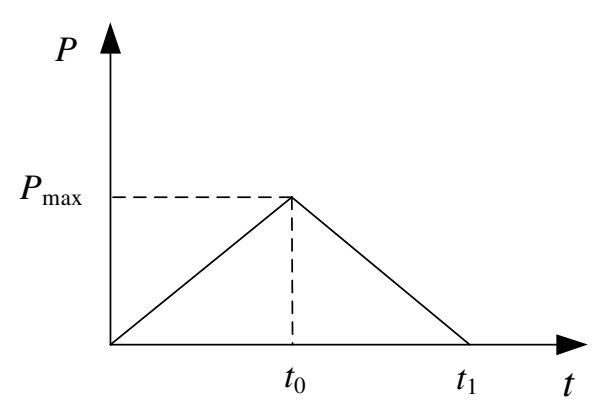

Figure 7 Simplified time history curve of gas explosion load

In this calculation, referring to the "Building Structure Load Code", the explosion load is simplified to a uniform load that changes linearly with time to simulate an explosion load, and it is applied to the warehouse wall, beam, slab, and column.

Because the impact force exerted by the explosion on the structure cannot be accurately estimated, the calculated load is mainly estimated based on the on-site damage condition and the explosion pressure of the acetylene explosion:

(1) All the pre-embedded steel bars of the steel funnel at the bottom are broken. According to this load, the maximum instantaneous impact load applied to the warehouse wall and floor is $400 \mathrm{KN} / \mathrm{m} 2$. (2) According to the maximum explosion pressure of acetylene $1.058 \mathrm{M} \mathrm{Pa}$, considering the distance between the explosion point and the structural member, the maximum instantaneous impact load applied to the warehouse wall and floor is $800 \mathrm{KN} / \mathrm{m}^{2}$.

\section{Simulation of structural finite element model}

\section{Structural model}

The engineering example studied in this subject is the operation station on the acetylene branch of a branch of a chemical company in Shaanxi Province, China. The operation station is a reinforced concrete frame structure with a total building height of $20.5 \mathrm{~m}$. The elevation of the bottom layer is $7.28 \mathrm{~m}$, the elevation of the middle layer is 15.78 , and the elevation of the top layer is $20.5 \mathrm{~m}$. The cross-section size of each frame column is $800 \mathrm{~mm} \times 800 \mathrm{~mm}$, and the column concrete grade is C30; the beam section size is $300 \mathrm{~mm} \times 600 \mathrm{~mm}$, and the concrete strength grade is C30; the floor thickness 
is $120 \mathrm{~mm}$, and the concrete strength grade is C 30 . The detailed finite element model of the structure is shown in Fig.8.

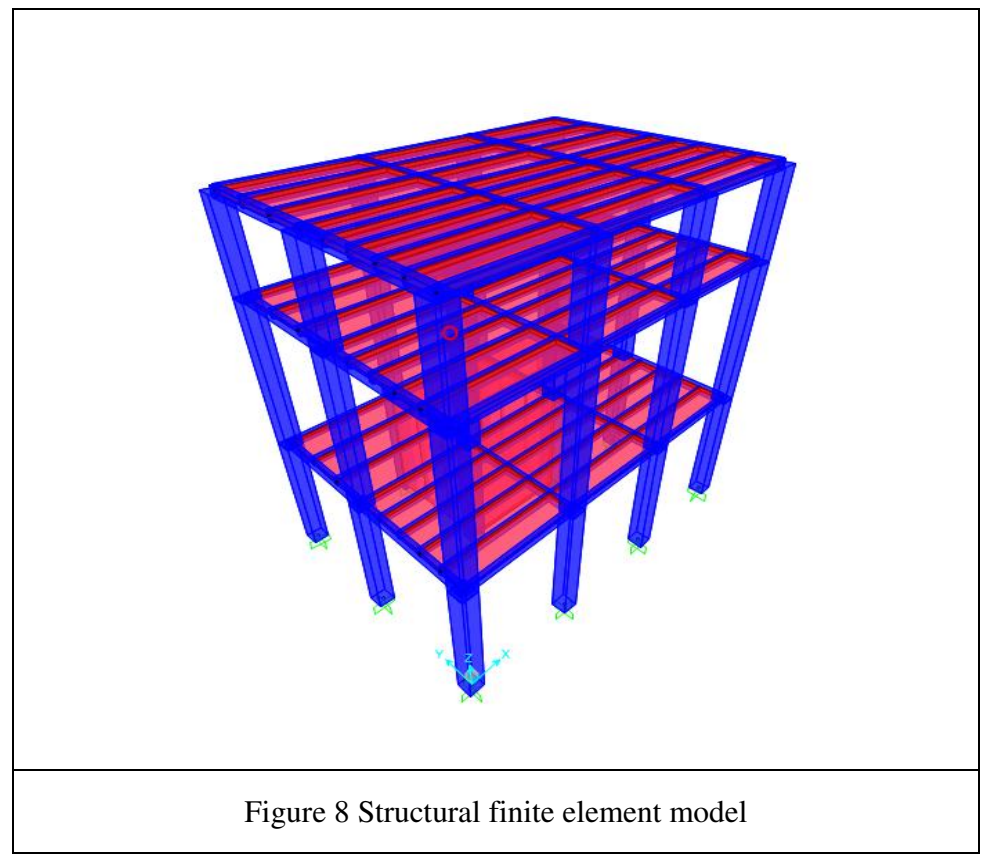

\section{Estimation of peak explosion load of acetylene-mixed gas}

Due to the particularity of acetylene-mixed gas explosion load, short time and large impulse, its peak value is difficult to be measured by specific tests. According to relevant information, the peak value of gas explosion load is generally very small, around $25-50 \mathrm{KPa}$. The acetylene-mixed gas explosion boost time is slow, the time is generally $100 \mathrm{~ms}-300 \mathrm{~ms}$. Combined with the simplified time history curve of acetylene-mixed gas explosion load in Figure 3.10 of this article, the peak values of the loading curve are $20 \mathrm{KPa}, 30 \mathrm{KPa}, 40 \mathrm{KPa}$, and the loading time is $0.2 \mathrm{~s}$. Add three kinds of explosive loads to the model (3-B 3-C axis/3-3 3-4 axis) where the explosion occurred in the building and workshop. Simplified explosive loads are applied to beams, slabs, columns and other components that directly bear explosive loads, as shown in Fig.9. 


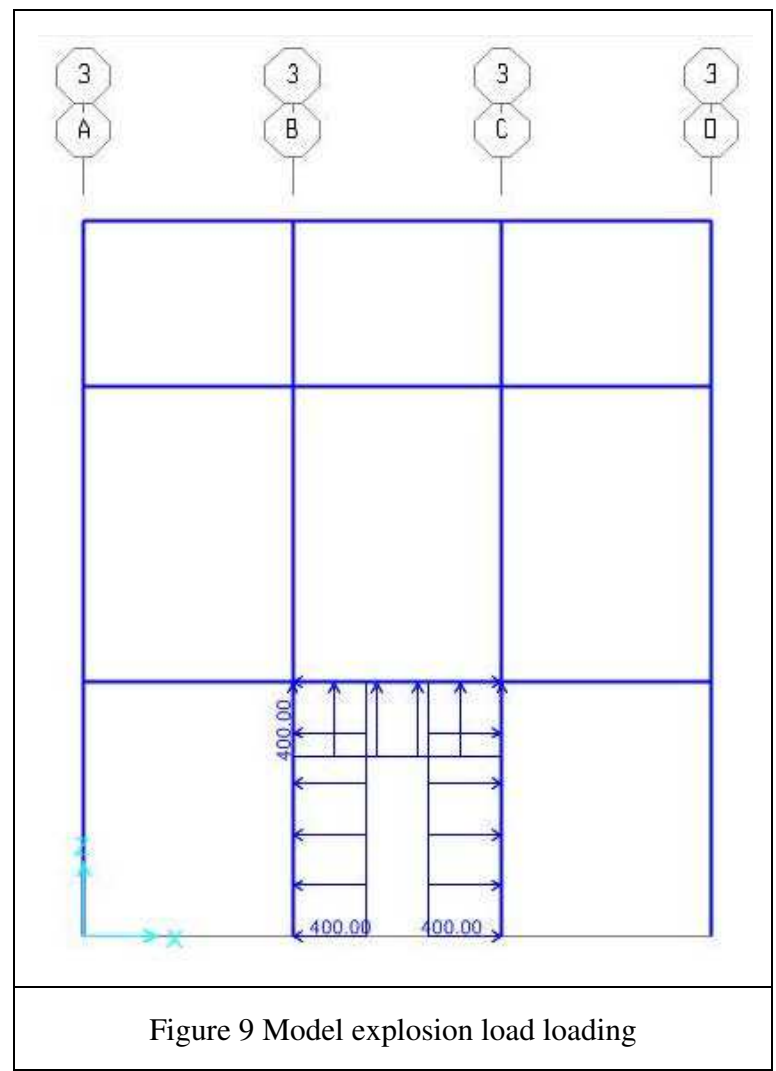

\section{Comparison of numerical simulation results with real accidents}

\section{Stress cloud diagram of blasted floor slab}

According to the investigation report on the accident site, the explosion silo was seriously damaged, the beam reinforcement around the silo yielded, and the concrete outside the beam was severely broken and falling off. The damage to the structure is shown in Fig.10.

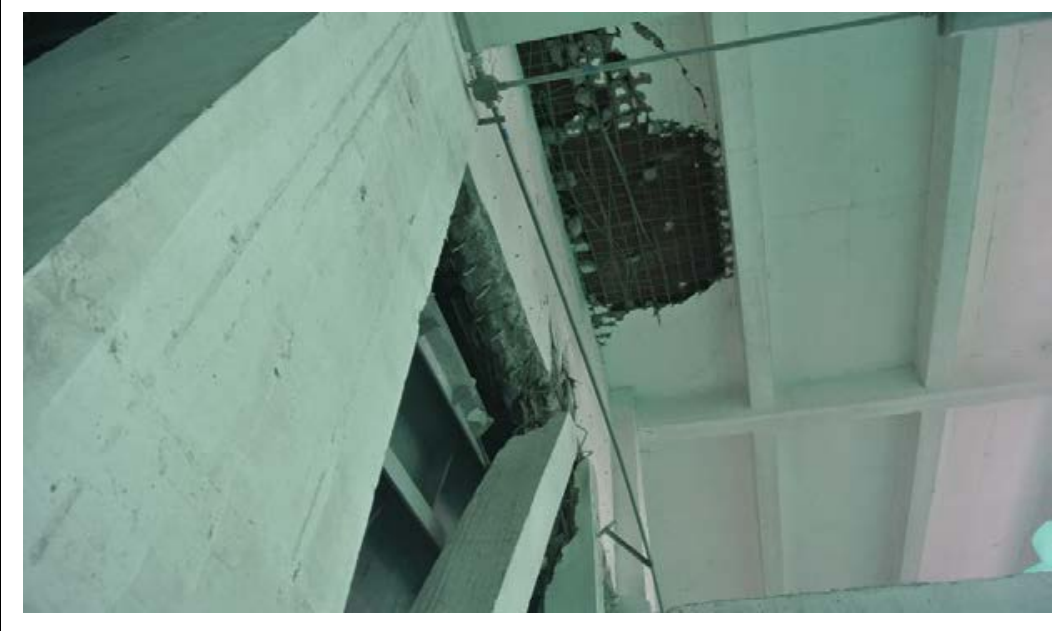


Figure 10 Destruction of floor slab subjected to explosive load

Through the simulation of the finite element software SAP2000, when the peak of the mixed gas explosion load is $40 \mathrm{KPa}$, the stress cloud diagram of the first, second and third floors of the structure is shown in Fig.11.

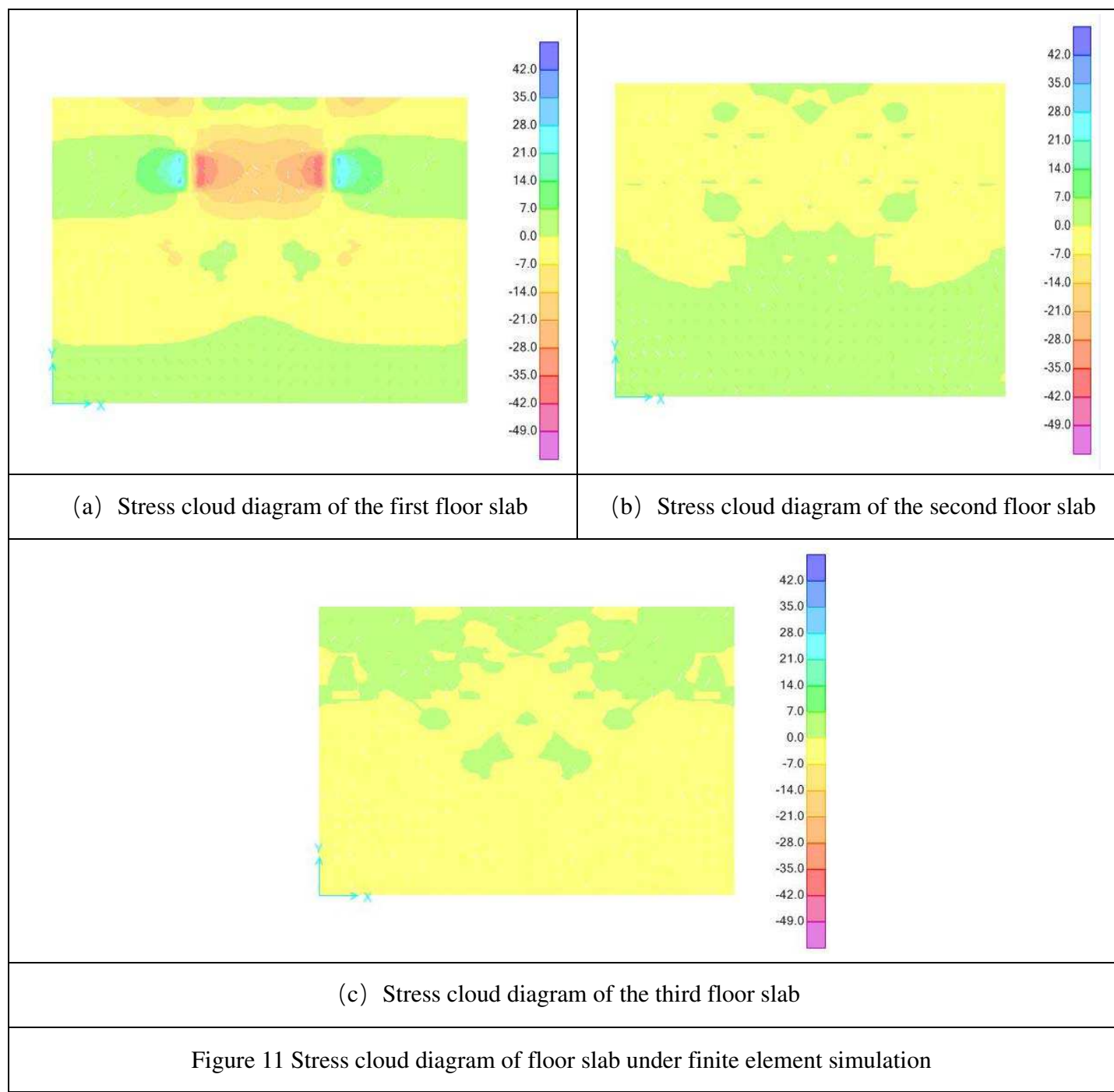

Through the finite element simulation of the structure by SAP2000, combined with the actual phenomenon of the structure, the specific longitudinal hinge situation of the model structure can be known. 


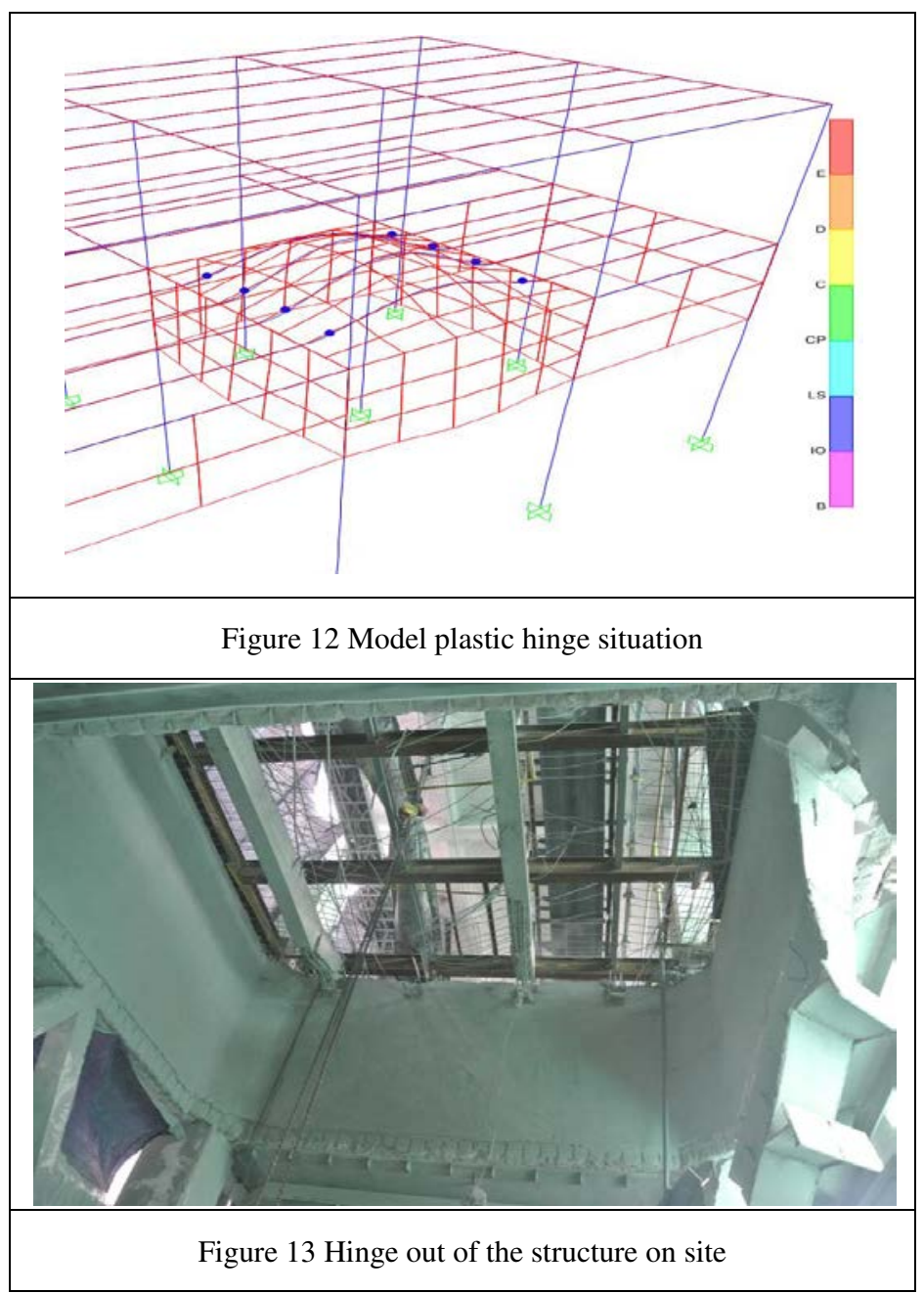

Set the load curves of the explosion peak load as $20 \mathrm{KPa}, 30 \mathrm{KPa}$, and $40 \mathrm{KPa}$, respectively, and apply them to the beams, columns, and slabs of the model. The final finite element simulation result is compared with the actual accident, and the change of the stress cloud diagram of the floor slab is more consistent with the actual damage. The final hinges of beams and columns are more consistent with the actual situation, which proves that the SAP2000 simulation results are more credible.

\section{Dynamic response analysis of frame columns under different peak explosive loads}

\section{Selection of Reinforced Concrete Material Parameters}

The structure adopts C30 concrete. When the model finite element simulation is performed, the concrete material is regarded as a homogeneous material, ignoring the original defects, and the 
material properties such as elastic modulus and bulk density are equivalent. For details of the materials used in this article, see Table 1.

Table 1 Details of the materials used in the model

\begin{tabular}{lccccc}
\hline \multicolumn{2}{c}{ Material Type } & $\begin{array}{c}\text { Elastic } \\
\text { Modulus }\end{array}$ & Density & $\begin{array}{c}\text { Volumetric } \\
\text { Weight }\end{array}$ & Poisson's Ratio \\
& C30 & $3.0 \times 10^{4}$ & 2500 & 24.5 & 0.2 \\
Concrete & HRB400 & $2.0 \times 10^{5}$ & 7800 & - & 0.3 \\
\hline
\end{tabular}

\section{Load condition setting}

In order to make the model closer to the real situation under the acetylene-mixed gas explosion load, in addition to the self-weight of the model, the wall constant load $\mathrm{q}=8.0 \mathrm{KN} / \mathrm{m}$, the floor constant load is $2.0 \mathrm{KN} / \mathrm{m}^{2}$, the floor live load is $3.0 \mathrm{KN} / \mathrm{m}^{2}$.

In order to study the influence of different peak explosive loads on the structure, three working conditions are selected as shown in Fig.14. Apply the explosive load to the position of the silo, and apply the time-varying linear load and surface load to the beams, columns, and slabs in the area.

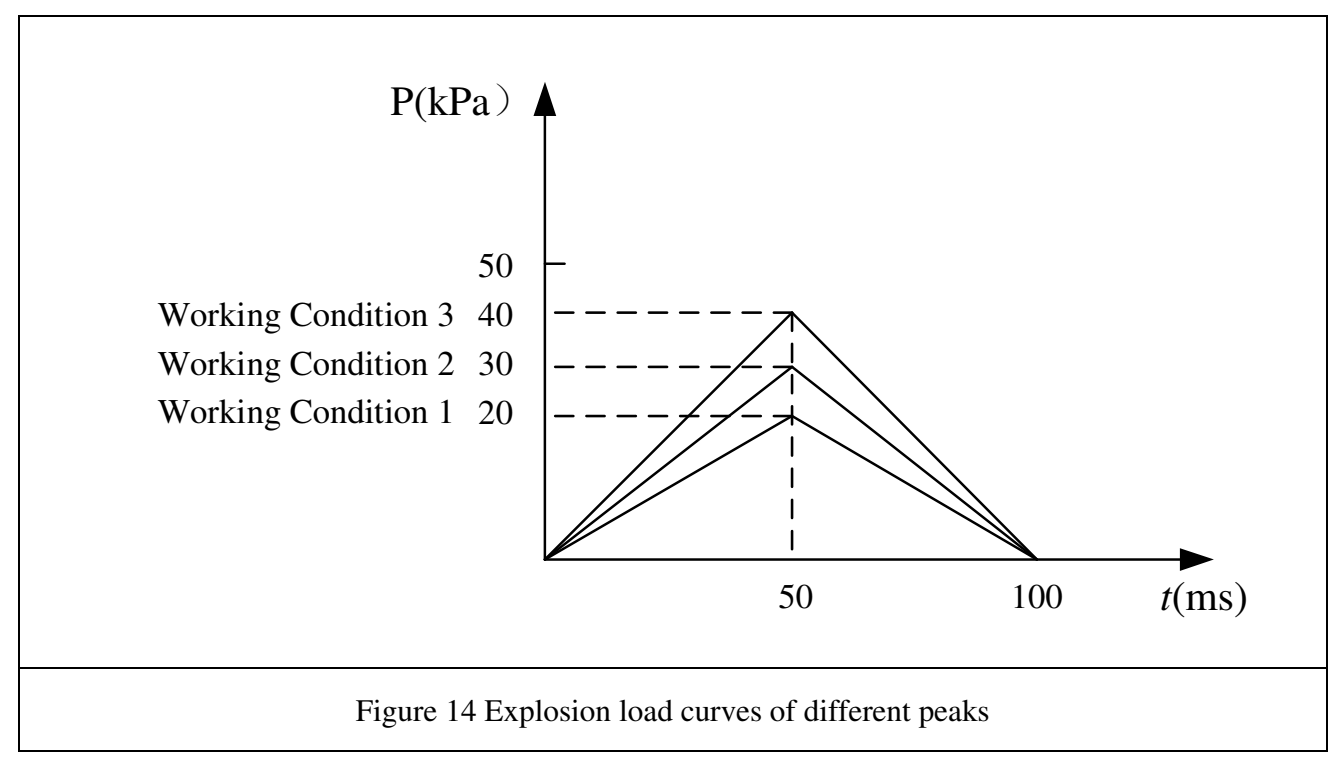

\section{Displacement response of frame columns}

The acetylene-mixed gas explosion peak loads of $20 \mathrm{KPa}, 30 \mathrm{KPa}$, and $40 \mathrm{KPa}$ in Working Condition 1, Working Condition 2, and Working Condition 3 are respectively converted into linear loads of $12 \mathrm{KN} / \mathrm{m}$ and $6 \mathrm{KN} / \mathrm{m}, 12 \mathrm{KN} / \mathrm{m}$ and $6 \mathrm{KN} / \mathrm{m}, 12 \mathrm{KN} / \mathrm{m}$ and $6 \mathrm{KN} / \mathrm{m}$ are added to the beams 
and columns of the frame as shown in Fig.7. The explosion impact load on the slab is $20 \mathrm{KN} / \mathrm{m}^{2}$, $30 \mathrm{KN} / \mathrm{m}^{2}, 40 \mathrm{KN} / \mathrm{m}^{2}$, and the explosion load curve is set in the form of a triangular broken line that changes with time, and the explosion duration is $0.2 \mathrm{~s}$. The node code and maximum displacement value of the frame column on the first floor under different working conditions are shown in Fig.15 and Table 2, respectively.

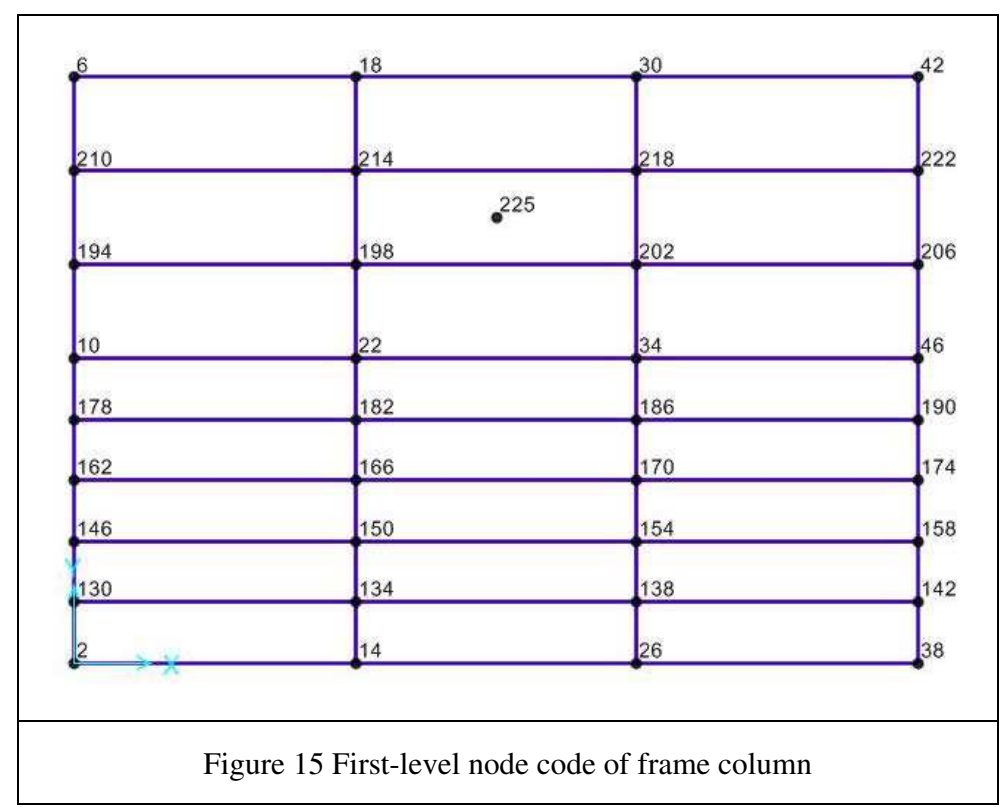

Table 2 Maximum displacement of first-floor node of frame column

\begin{tabular}{cccccccc}
\hline \multicolumn{7}{c}{ Working condition 1 } \\
\hline Position & A-1 & A-9 & A-6 & B-1 & B-9 & B-6 & C-1 \\
\hline Node coding & 2 & 6 & 10 & 14 & 18 & 22 & 26 \\
\hline U1 & $3 \mathrm{E}-06$ & $1.2 \mathrm{E}-05$ & $4.64 \mathrm{E}-06$ & $1.15 \mathrm{E}-06$ & $6 \mathrm{E}-06$ & $1.7 \mathrm{E}-06$ & $1.36 \mathrm{E}-06$ \\
\hline $\mathrm{U} 2$ & $2.1 \mathrm{E}-05$ & $2.4 \mathrm{E}-05$ & $2.1 \mathrm{E}-05$ & $2.4 \mathrm{E}-05$ & $2 \mathrm{E}-05$ & $2.2 \mathrm{E}-05$ & $2.4 \mathrm{E}-05$ \\
\hline $\mathrm{U} 3$ & $1.61 \mathrm{E}-06$ & $1.6 \mathrm{E}-05$ & $1.7 \mathrm{E}-05$ & $6.3 \mathrm{E}-06$ & $3.2 \mathrm{E}-05$ & $3.2 \mathrm{E}-05$ & $6.3 \mathrm{E}-06$ \\
\hline
\end{tabular}

It can be seen from Fig. 15 and Table 2 that after the explosion load occurs, the $\mathrm{X}$ and $\mathrm{Y}$ direction displacement of each node of the frame column is larger than the $\mathrm{Z}$ direction displacement. The intersection of the A-9 axis and the B-9 axis are separated from each other. The explosion load is relatively close, and the displacement value is larger than that of other nodes. From the data in the table, it can be concluded that the displacement value of the intersection point of the A-9 axis and the intersection point of the B-9 axis of the frame closer to the explosion load is larger, and the node 
far away from the explosion load has a smaller displacement and is basically not damaged. It shows that the explosion load has local damage to the structure.

Comparing Table 2 and Table 3, it can be seen that the displacement value of each node under Working Condition 2 is significantly larger than that of Working Condition 1, which is about 3 times that of Working Condition 1 . The joint displacement increases continuously with the increase of the explosion load.

Table 3 Maximum displacement of first-floor node of frame column

\begin{tabular}{cccccccc}
\hline \multicolumn{7}{c}{ Working condition 2} \\
\hline Position & A-1 & A-9 & A-6 & B-1 & B-9 & B-6 & C-1 \\
\hline Node coding & 2 & 6 & 10 & 14 & 18 & 22 & 26 \\
\hline U1 & $7.21 \mathrm{E}-06$ & $2.1 \mathrm{E}-05$ & $1.1 \mathrm{E}-05$ & $3.2 \mathrm{E}-06$ & $1 \mathrm{E}-05$ & $3.9 \mathrm{E}-06$ & $3.21 \mathrm{E}-06$ \\
\hline $\mathrm{U} 2$ & $4.9 \mathrm{E}-05$ & $5.7 \mathrm{E}-05$ & $5.1 \mathrm{E}-05$ & $5.2 \mathrm{E}-05$ & $4.9 \mathrm{E}-05$ & $5.1 \mathrm{E}-05$ & $5.2 \mathrm{E}-05$ \\
\hline U3 & $3.9 \mathrm{E}-06$ & $3 \mathrm{E}-05$ & $3.4 \mathrm{E}-05$ & $1.1 \mathrm{E}-05$ & $6.9 \mathrm{E}-05$ & $6.9 \mathrm{E}-05$ & $1.1 \mathrm{E}-05$ \\
\hline
\end{tabular}

The coding of B-axis frame node is shown in Fig.16:

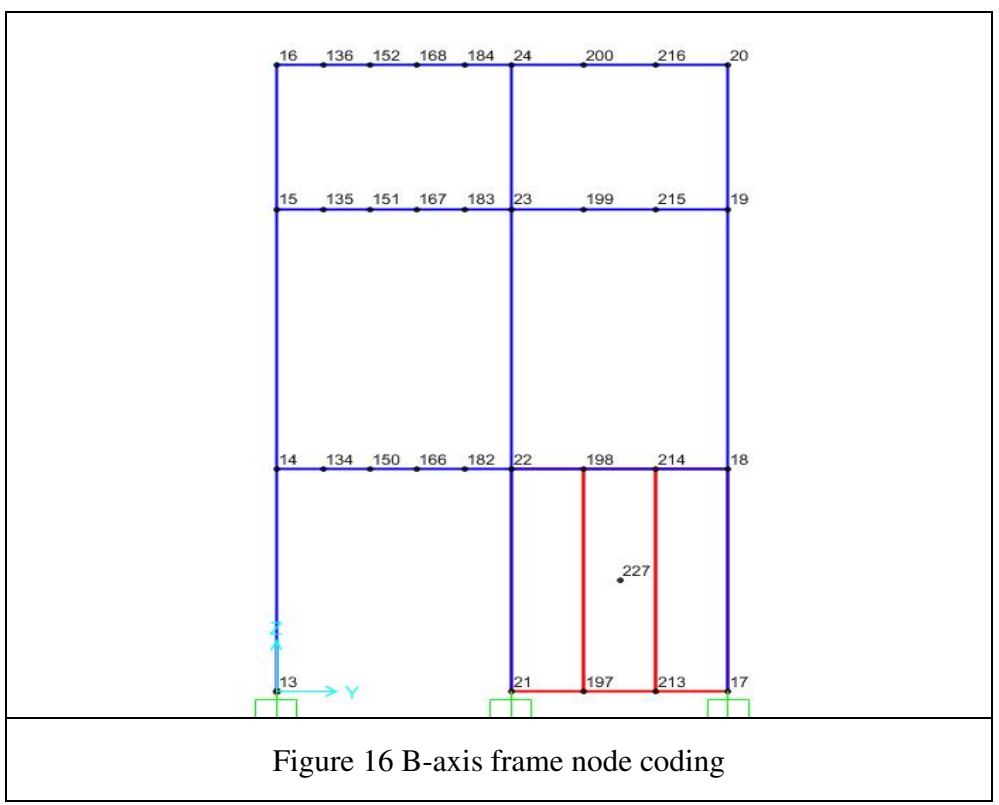

Table 4 Maximum displacement of each node of B-axis single frame frame

\begin{tabular}{cccccccc}
\hline \multicolumn{7}{c}{ Working condition 1} \\
\hline Position & B-1 & B-1 & B-1 & B-9 & B-9 & B-9 & B-6 \\
\hline Node coding & 14 & 15 & 16 & 18 & 19 & 20 & 22 \\
\hline
\end{tabular}




\begin{tabular}{cccccccc}
\hline $\mathrm{U} 1$ & $1.4 \mathrm{E}-06$ & $3.9 \mathrm{E}-07$ & $2.58 \mathrm{E}-07$ & $6 \mathrm{E}-06$ & $7.95 \mathrm{E}-07$ & $2.9 \mathrm{E}-07$ & $1.7 \mathrm{E}-06$ \\
\hline $\mathrm{U} 2$ & $2.4 \mathrm{E}-05$ & $2.9 \mathrm{E}-05$ & $2.7 \mathrm{E}-05$ & $2 \mathrm{E}-05$ & $2.8 \mathrm{E}-05$ & $2.7 \mathrm{E}-05$ & $2.2 \mathrm{E}-05$ \\
\hline $\mathrm{U} 3$ & $6.3 \mathrm{E}-06$ & $8.2 \mathrm{E}-06$ & $9.2 \mathrm{E}-06$ & $3.2 \mathrm{E}-05$ & $3.2 \mathrm{E}-05$ & $3.2 \mathrm{E}-05$ & $3.2 \mathrm{E}-05$ \\
\hline
\end{tabular}

Table 5 Maximum displacement of each node of B-axis single frame frame

\begin{tabular}{cccccccc}
\hline \multicolumn{7}{c}{ Working condition 2} \\
\hline Position & B-1 & B-1 & B-1 & B-9 & B-9 & B-9 & B-6 \\
\hline Node coding & 14 & 15 & 16 & 18 & 19 & 20 & 22 \\
\hline U1 & $3.2 \mathrm{E}-06$ & $7.28 \mathrm{E}-07$ & $5.1 \mathrm{E}-07$ & $1 \mathrm{E}-05$ & $1.6 \mathrm{E}-06$ & $6.1 \mathrm{E}-07$ & $3.9 \mathrm{E}-06$ \\
\hline $\mathrm{U} 2$ & $5.2 \mathrm{E}-05$ & $5.2 \mathrm{E}-05$ & $5.9 \mathrm{E}-05$ & $4.9 \mathrm{E}-05$ & $5.4 \mathrm{E}-05$ & $6 \mathrm{E}-05$ & $5.1 \mathrm{E}-05$ \\
\hline $\mathrm{U} 3$ & $1.1 \mathrm{E}-05$ & $1.6 \mathrm{E}-05$ & $1.8 \mathrm{E}-05$ & $6.9 \mathrm{E}-05$ & $6.9 \mathrm{E}-05$ & $6.9 \mathrm{E}-05$ & $6.9 \mathrm{E}-05$ \\
\hline
\end{tabular}

From the data in the Table 4, it can be concluded that the displacement value of the intersection point of the A-9 axis and the intersection point of the B-9 axis of the frame closer to the explosion load is larger, and the node far away from the explosion load has a smaller displacement and is basically not damaged. It shows that the explosion load has local damage to the structure. Comparing the corresponding values in Table 4 and Table 5, we can know that the displacement value of the frame node in the second case is greater than the corresponding node displacement value in the first case. It can be seen that the displacement value of the frame node increases with the increase of the explosion peak load.

\section{Acceleration response of frame columns}

Take the B-axis single frame frame as an example to illustrate the acceleration change law of frame columns under the action of acetylene-mixed gas explosion load. Under different working conditions, the acceleration peak values of the frame columns are shown in Tables 6 and 7.

Table 6 Maximum acceleration of each node of the B-axis single-blade frame

\begin{tabular}{ccccccc}
\hline \multicolumn{6}{c}{ Working condition 1} \\
\hline \multirow{3}{*}{ Position } & B-1 & B-1 & B-1 & B-9 & B-9 & B-9 \\
& First floor & Second floor & Third floor & First floor & Second floor & Third floor \\
\hline
\end{tabular}




\begin{tabular}{ccccccc}
\hline Node coding & 14 & 15 & 16 & 18 & 19 & 20 \\
\hline $\mathrm{U} 1$ & 0.074 & 0.010 & 0.008 & 0.050 & 0.010 & 0.008 \\
\hline $\mathrm{U} 2$ & 0.274 & 0.067 & 0.049 & 0.490 & 0.068 & 0.043 \\
\hline $\mathrm{U} 3$ & 0.105 & 0.129 & 0.137 & 0.275 & 0.229 & 0.289 \\
\hline
\end{tabular}

It can be seen from Table 6 that as the number of layers increases, the acceleration response of the frame nodes becomes smaller. The acceleration response of the frame nodes is the largest on the first floor and the smallest on the third floor. This is because the explosion load occurs between the B-C axis on the first floor. Affected by the explosion load, the Y-direction and Z-direction acceleration response of each node is larger. This is because the structure has more X-direction connections and greater rigidity, which is less affected by the load. Comparing Table 6 and Table 7 , we can see:

Table 7 Maximum acceleration of each node of the B-axis single-blade frame

\begin{tabular}{ccccccc}
\hline \multirow{7}{*}{ Position } & B-1 & B-1 & B-1 & B-9 & B-9 & B-9 \\
& First floor & Second floor & Third floor & First floor & Second floor & Third floor \\
\hline Node coding & 14 & 15 & 16 & 18 & 19 & 20 \\
\hline U1 & 0.322 & 0.023 & 0.026 & 0.150 & 0.024 & 0.026 \\
\hline U2 & 1.194 & 0.164 & 0.091 & 1.654 & 0.177 & 0.094 \\
\hline U3 & 0.202 & 0.309 & 0.346 & 0.852 & 0.906 & 1.248 \\
\hline
\end{tabular}

The acceleration response of the node in the second condition is larger than the acceleration response of the corresponding node in the first condition, which is about 3 times that of the first condition. It can be seen that the acceleration response of the frame column increases with the increase of the peak load of the acetylene-mixed gas explosion.

\section{Research on dynamic response of floor slab}

\section{Displacement response of floor slab}


Under the explosive load of acetylene-mixed gas, the overall deformation of the structure is shown in Fig.17.

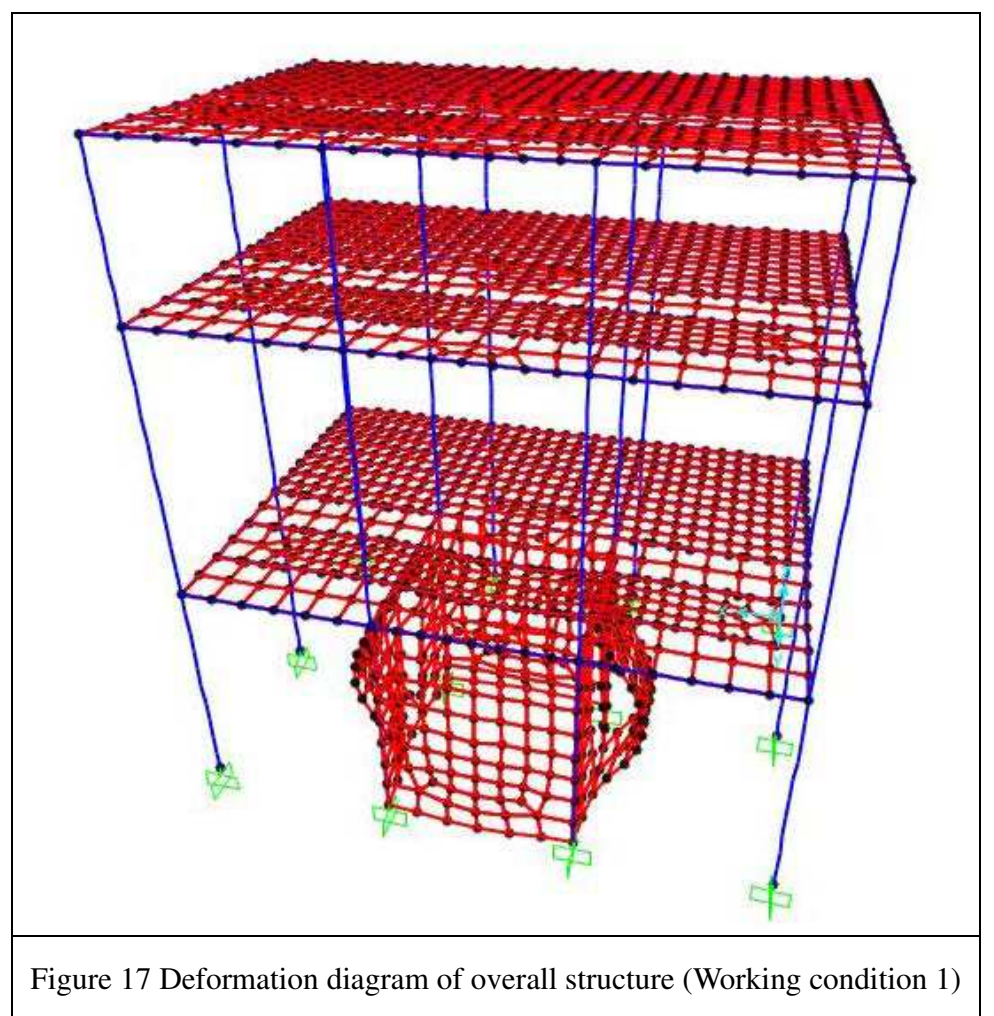

It can be seen from Fig. 17 that under the action of the explosion load, the overall deformation of the structure is relatively small, and the silo wall around the explosion load is relatively large. One side slab has been exploded, the first floor has been greatly disturbed, and the second and third floor slabs are basically intact. Fig.18 Deformation diagram of the overall structure under the second load of working condition, it can be seen from the figure: 


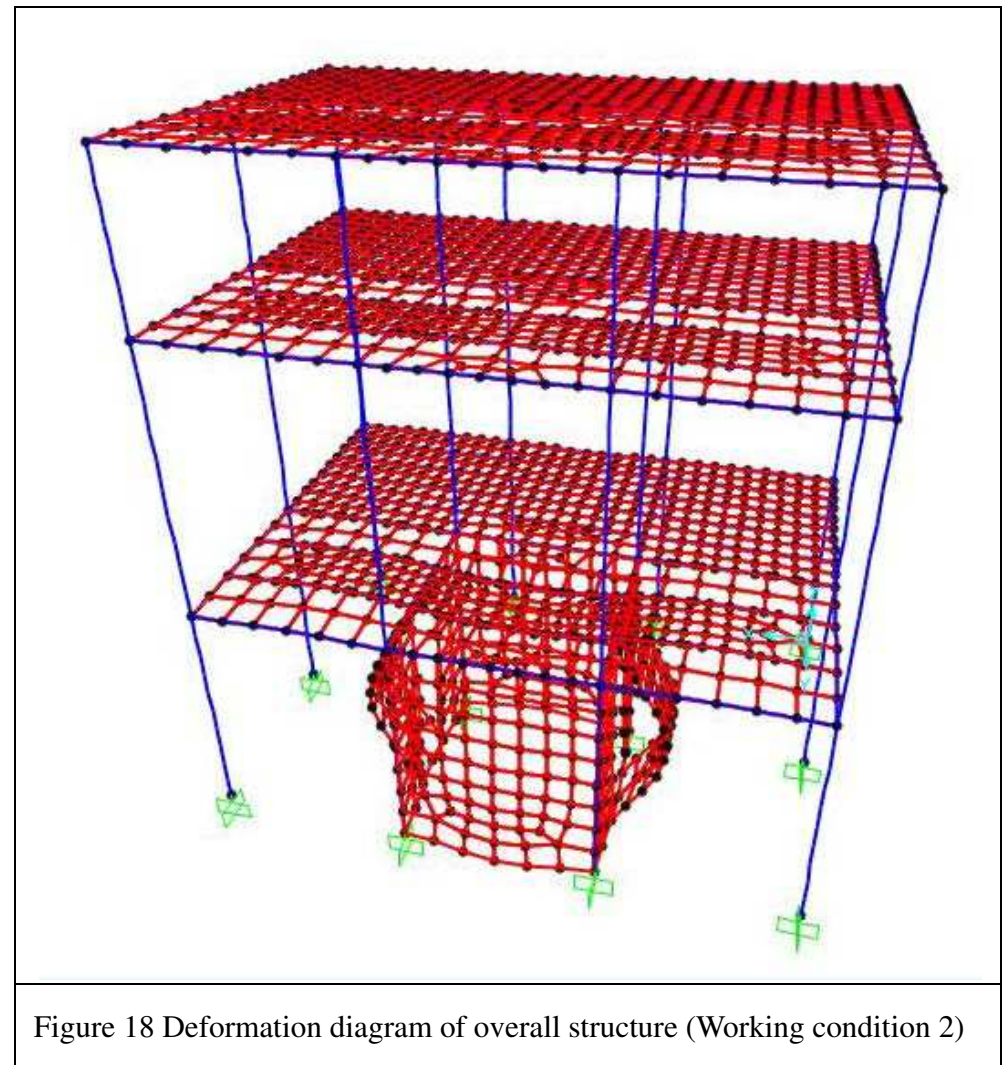

There is not much difference in the shape of the overall deformation diagram under working condition 2 and working condition 1, and the deformation of the structure under working condition 22 is greater than that of working condition 1 .

The displacement response values of the structural concrete floor and warehouse wall are shown in Tables 8 and 9. From the values in the table, you can:

Table 8 Maximum displacement of structural concrete slab and warehouse wall

\begin{tabular}{|c|c|c|c|c|c|}
\hline \multicolumn{6}{|c|}{ Working condition 1} \\
\hline Position & Silo roof & C-axis silo board & B-axis silo board & 6-axis silo board & 9-axis silo board \\
\hline Node coding & 225 & 226 & 227 & 228 & 229 \\
\hline $\mathrm{U} 1$ & $1.6 \mathrm{E}-08$ & 0.033 & 0.033 & $1.1 \mathrm{E}-08$ & $1.0 \mathrm{E}-08$ \\
\hline $\mathrm{U} 2$ & $2 \mathrm{E}-05$ & $1.7 \mathrm{E}-05$ & $1.7 \mathrm{E}-05$ & 0.006 & 0.006 \\
\hline U3 & 0.002 & $6.4 \mathrm{E}-05$ & $6.4 \mathrm{E}-05$ & $2 \mathrm{E}-05$ & $2.2 \mathrm{E}-05$ \\
\hline
\end{tabular}

It is concluded that the displacement value in the direction perpendicular to the plate surface is larger than the displacement value in the other two directions, such as node 225 , the displacement value in the $\mathrm{Z}$ direction perpendicular to the plate surface is 0.002 , and the displacement in the $\mathrm{Y}$ direction is $2 \mathrm{E}-05$. Because the lateral stiffness of the plate is smaller, the displacement value of the 
plate is larger than that of the column. Comparing the displacement values of the nodes in the vertical slab direction, it can be seen that their magnitudes are the same, that is, the impact of the explosive load on the surrounding structure is isotropic. Comparing Table 8 and Table 9 , it can be seen that the displacement response of the plate under the explosion load increases with the increase of the peak value of the explosion load.

Table 9 Maximum displacement of structural concrete slab and warehouse wall

\begin{tabular}{|c|c|c|c|c|c|}
\hline \multicolumn{6}{|c|}{ Working condition 2} \\
\hline Position & Silo roof & C-axis silo board & B-axis silo board & 6-axis silo board & 9-axis silo board \\
\hline Node coding & 225 & 226 & 227 & 228 & 229 \\
\hline U1 & $3.1 \mathrm{E}-08$ & 0.065 & 0.065 & $2.2 \mathrm{E}-08$ & $2 \mathrm{E}-08$ \\
\hline $\mathrm{U} 2$ & 4.9E-05 & 4.3E-05 & 4.3E-05 & 0.012 & 0.012 \\
\hline $\mathrm{U} 3$ & 0.004 & $1.6 \mathrm{E}-04$ & $1.6 \mathrm{E}-04$ & 4.2E-05 & $4.6 \mathrm{E}-05$ \\
\hline
\end{tabular}

The displacement of the structural warehouse wall under the explosion load is shown in Fig.19:

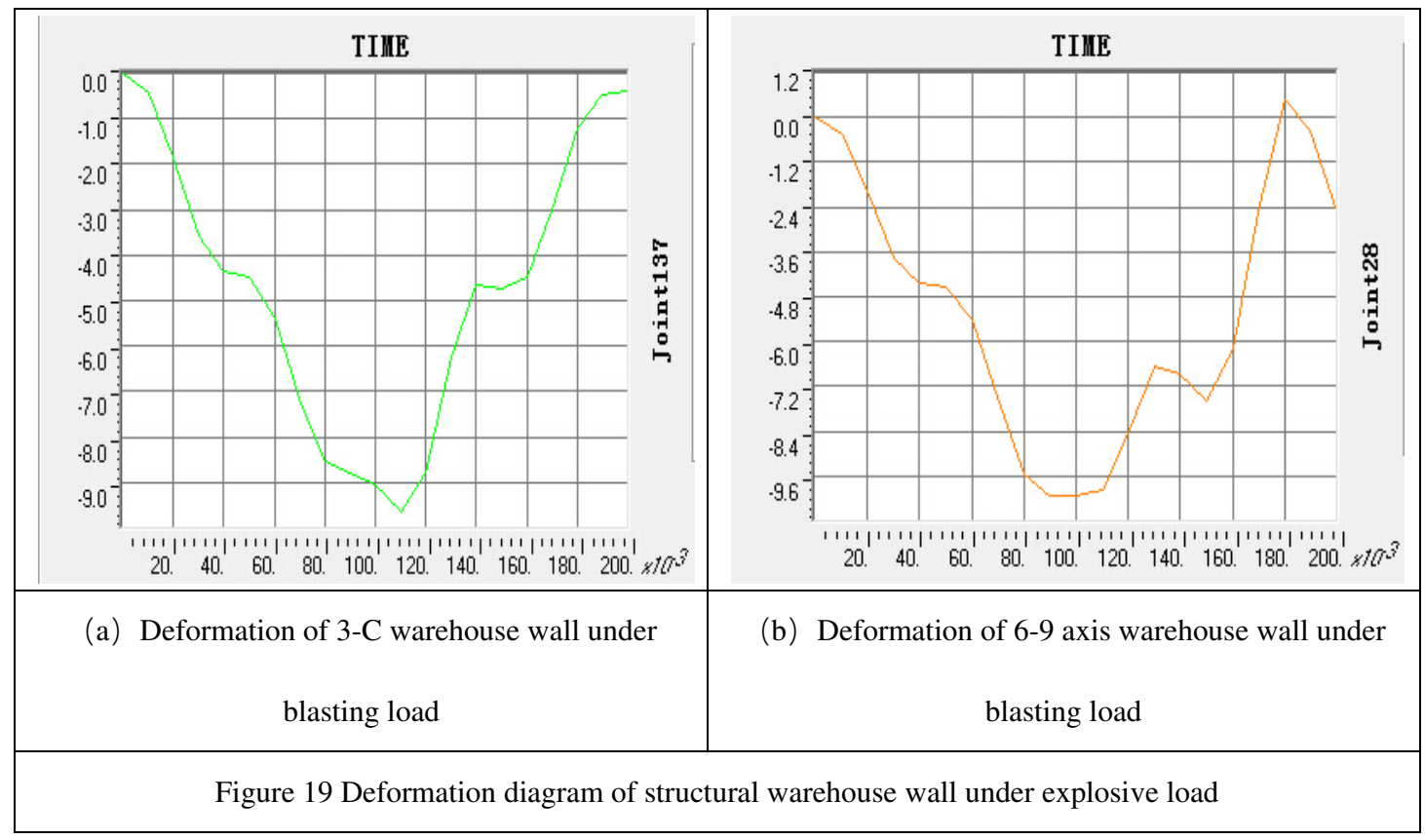

\section{Acceleration response of floor slab}

Under the explosive load of acetylene-mixed gas, the acceleration response of the structural warehouse wall and floor slab is shown in Tables 10 and 11.

Table 10 Acceleration response of structural warehouse wall and floor 


\begin{tabular}{|c|c|c|c|c|c|}
\hline \multicolumn{6}{|c|}{ Working condition 1} \\
\hline Position & Silo roof & C-axis silo board & B-axis silo board & 6-axis silo board & 9-axis silo board \\
\hline Node coding & 225 & 226 & 227 & 228 & 229 \\
\hline U1 & 7.4E-04 & 57.8 & 57.8 & 0.002 & 0.002 \\
\hline $\mathrm{U} 2$ & 0.146 & 0.461 & 0.460 & 7.3 & 9.4 \\
\hline U3 & 12.4 & 2.7 & 2.7 & 0.354 & 0.370 \\
\hline \multicolumn{6}{|c|}{ Table 11 Acceleration response of structural warehouse wall and floor } \\
\hline \multicolumn{6}{|c|}{ Working condition 2} \\
\hline Position & Silo roof & C-axis silo board & B-axis silo board & 6-axis silo board & 9-axis silo board \\
\hline Node coding & 225 & 226 & 227 & 228 & 229 \\
\hline U1 & 0.003 & 110.2 & 110.2 & 0.008 & 0.008 \\
\hline $\mathrm{U} 2$ & 0.514 & 2.1 & 2.1 & 15.9 & 18.9 \\
\hline $\mathrm{U} 3$ & 23.4 & 10.4 & 10.4 & 1.4 & 1.3 \\
\hline
\end{tabular}

It can be seen from Tables 10 and 11 that the silo wall and floor are directly affected by the explosion load, and the acceleration response is more obvious. The acceleration response in the direction perpendicular to the slab surface is more obvious than the acceleration response in the other two directions. The acceleration response of the $\mathrm{C}$-axis and $\mathrm{B}$-axis silo is larger than the acceleration value in other directions. Comparing Tables 10 and 11, we can get that the acceleration value under working condition 2 is larger than the acceleration value of the corresponding node under working condition 1 below. That is, the structure is subjected to the explosive load, and the acceleration response of the warehouse wall and floor slab becomes larger as the peak value of the explosive load increases.

\section{Research on the dynamic response of frame beams}

\section{Displacement response of frame beam}

The maximum displacement value of frame beam under explosive load is shown in Table 12 and 
13.

Table 12 Maximum displacement value of each node of the first layer beam of the frame

\begin{tabular}{ccccccccc}
\hline \multicolumn{7}{c}{ Working condition 1 } \\
\hline Position & B-6 & C-6 & A-7 & B-7 & C-7 & D-7 & A-8 & B-8 \\
\hline Node coding & 22 & 34 & 194 & 198 & 202 & 206 & 210 & 214 \\
\hline U1 & $1.7 \mathrm{E}-06$ & $1.7 \mathrm{E}-06$ & $6.3 \mathrm{E}-06$ & $1.1 \mathrm{E}-05$ & $1.1 \mathrm{E}-05$ & $6.3 \mathrm{E}-06$ & $8.8 \mathrm{E}-06$ & $1.2 \mathrm{E}-05$ \\
\hline $\mathrm{U} 2$ & $2.2 \mathrm{E}-05$ & $2.2 \mathrm{E}-05$ & $2.2 \mathrm{E}-05$ & $2.1 \mathrm{E}-05$ & $2.2 \mathrm{E}-05$ & $2.2 \mathrm{E}-05$ & $2.3 \mathrm{E}-05$ & $2 \mathrm{E}-05$ \\
\hline $\mathrm{U} 3$ & $3.2 \mathrm{E}-05$ & $3.2 \mathrm{E}-05$ & $3.7 \mathrm{E}-04$ & $4.7 \mathrm{E}-05$ & $4.7 \mathrm{E}-05$ & $3.7 \mathrm{E}-04$ & $3.8 \mathrm{E}-04$ & $4.8 \mathrm{E}-05$ \\
\hline
\end{tabular}

It can be seen from Tables 12 and 13 that the frame beam is subjected to explosive load, the displacement value of the vertical beam in the $\mathrm{Z}$ direction is the largest, and the displacement value in the $\mathrm{X}$ and $\mathrm{Y}$ directions is smaller. Since the 7th and 8th axis are relatively close to the explosion load, the displacement value of the 7th and 8th axis is larger than that of the 6th axis. Comparing the displacement values of the corresponding positions in Tables 12 and 13, the displacement value under working condition 2 is larger than that of working condition 1 , indicating that the displacement value of the frame beam increases with the increase of the peak explosion load.

Table 13 Maximum displacement value of each node of the first layer beam of the frame

\begin{tabular}{ccccccccc}
\hline \multicolumn{7}{c}{ Working condition 2} \\
\hline Position & B-6 & C-6 & A-7 & B-7 & C-7 & D-7 & A-8 & B-8 \\
\hline Node coding & 22 & 34 & 194 & 198 & 202 & 206 & 210 & 214 \\
\hline U1 & $3.9 \mathrm{E}-06$ & $3.8 \mathrm{E}-06$ & $1.3 \mathrm{E}-05$ & $2.2 \mathrm{E}-05$ & $2.2 \mathrm{E}-05$ & $1.3 \mathrm{E}-05$ & $1.6 \mathrm{E}-05$ & $2.4 \mathrm{E}-05$ \\
\hline $\mathrm{U} 2$ & $5.1 \mathrm{E}-05$ & $5.1 \mathrm{E}-05$ & $5.2 \mathrm{E}-05$ & $5 \mathrm{E}-05$ & $5 \mathrm{E}-05$ & $6.4 \mathrm{E}-04$ & $6.6 \mathrm{E}-04$ & $5 \mathrm{E}-05$ \\
\hline $\mathrm{U} 3$ & $6.9 \mathrm{E}-05$ & $6.9 \mathrm{E}-05$ & $6.4 \mathrm{E}-04$ & $2.3 \mathrm{E}-04$ & $2.3 \mathrm{E}-04$ & $7.2 \mathrm{E}-04$ & $7.4 \mathrm{E}-04$ & $2.3 \mathrm{E}-04$ \\
\hline
\end{tabular}

The stress diagram of the frame structure is shown in Fig.20: 


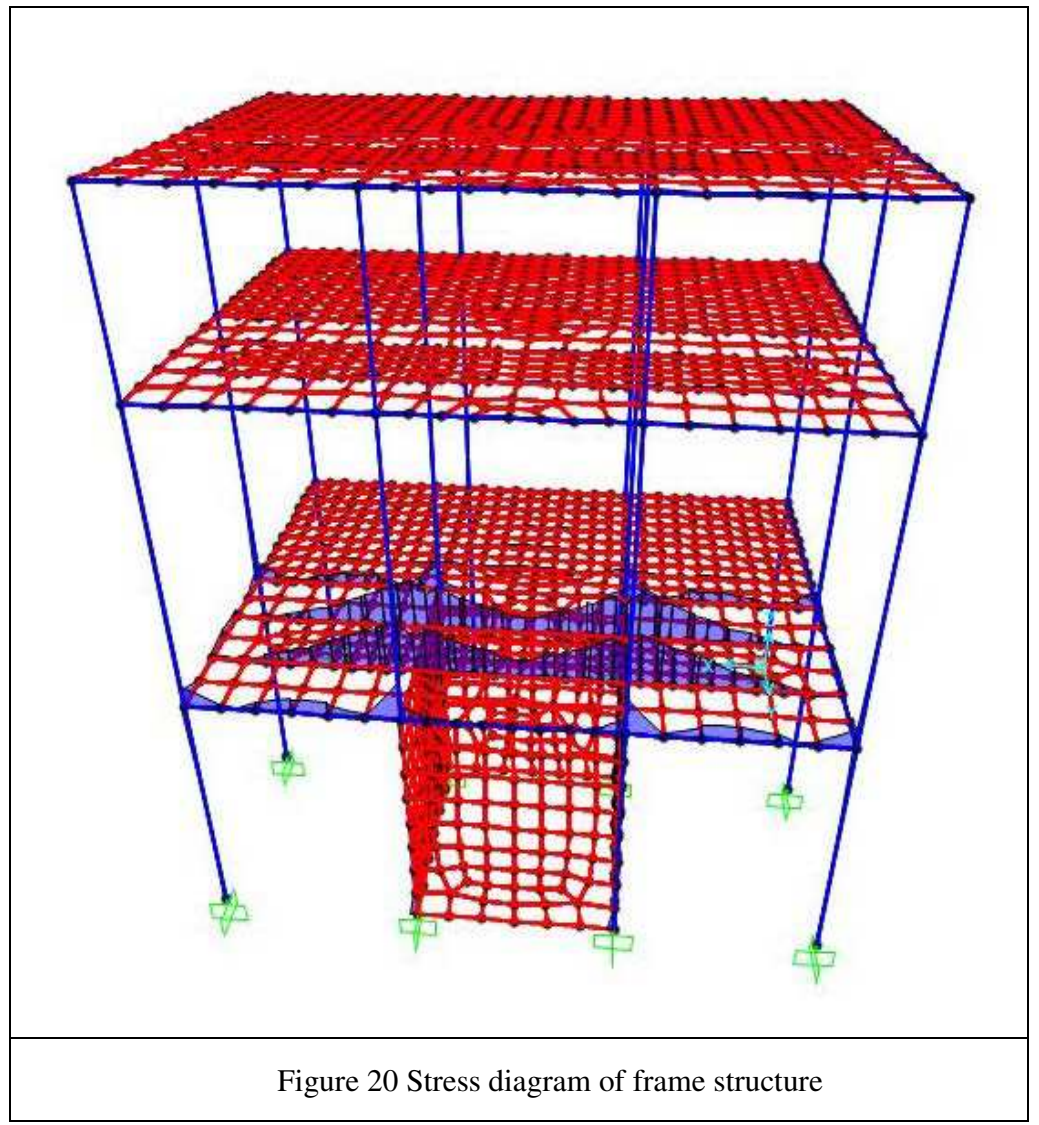

Acceleration response of frame beam

Under the explosive load of acetylene-mixed gas, the maximum acceleration of the frame beam can be seen in Table 14 and Table 15 in detail.

Table 14 Maximum acceleration of frame beams on the first floor

\begin{tabular}{cccccccc}
\hline \multicolumn{7}{c}{ Working condition 1 } \\
\hline Position & B-6 & C-6 & A-7 & B-7 & C-7 & D-7 & A-8 \\
\hline Node coding & 22 & 34 & 194 & 198 & 202 & 206 & 210 \\
\hline U1 & 0.053 & 0.053 & 0.17 & 0.101 & 0.101 & 0.17 & 0.135 \\
\hline U2 & 0.364 & 0.365 & 0.155 & 0.305 & 0.3055 & 0.155 & 0.209 \\
\hline U3 & 0.252 & 0.253 & 3.204 & 3.024 & 3.021 & 3.204 & 3.214 \\
\hline
\end{tabular}

Table 15 Maximum acceleration of frame beams on the first floor

Working condition 2 


\begin{tabular}{cccccccc}
\hline Position & B-6 & C-6 & A-7 & B-7 & C-7 & D-7 & A-8 \\
\hline Node coding & 22 & 34 & 194 & 198 & 202 & 206 & 210 \\
\hline U1 & 0.2111 & 0.210 & 0.667 & 0.25 & 0.259 & 0.668 & 0.387 \\
\hline U2 & 0.943 & 0.942 & 0.361 & 1.13 & 1.13 & 0.362 & 0.629 \\
\hline U3 & 0.978 & 0.979 & 7.384 & 8.689 & 8.681 & 7.384 & 7.335 \\
\hline
\end{tabular}

After comparing the data in Table 14 vertically and horizontally, it can be found that because the 7-axis node is close to the explosive load, the acceleration value of its node is larger than that of the 6-axis and the 8-axis. The acceleration response value of the frame beam is relatively large, and the value of the $\mathrm{Z}$ direction of the vertical beam is relatively large. Comparing the corresponding values in Table 14 and Table 15, we can see that the acceleration response value under working condition 2 is larger than that under working condition 1, about 3 to 4 times the value in working condition 1. That is, the acceleration response value of the frame beam increases with the increase of the peak value of the explosion load.

\section{Conclusions:}

This paper uses SAP2000 finite element software to simulate the damage of the building structure in real accidents, and study its structural deformation and failure characteristics under the action of explosive loads, and draw the following conclusions:

(1) The SAP2000 simulation results are basically consistent with the results of the engineering example, which proves the reliability of the finite element simulation; the damage caused by the explosion to the plate is particularly serious, and for the entire structure, the damage caused by the explosion is local.

(2) The dynamic response of frame beams, slabs, and columns uniformly increases with the increase of the explosion load. The frame beam is subjected to the explosive load. The vertical beam has the largest displacement value in the $\mathrm{Z}$ direction, and the displacement value in the $\mathrm{X}$ and $\mathrm{Y}$ directions is smaller. This is because the beam is exposed to the explosion load in the $\mathrm{Z}$ direction.

(3) The silo wall and floor are directly affected by the explosion load, and the acceleration response is more obvious. The acceleration response in the direction perpendicular to the slab surface is more 
obvious than the acceleration response in the other two directions. With the increase of the number of layers, the displacement value of the frame nodes gradually decreases, with the largest displacement on the first floor and the smallest on the third floor, that is, the explosion load will gradually attenuate as the load transfers.

\section{Acknowledgments}

The authors would like to gratefully acknowledge the financial supports from the National Natural Science Foundations of China (51278401). This funding provides financial support in collecting and analyzing information and in the decision to submit the article for publication.

\section{Data Availability Statement}

Some or all data, models, or code that support the findings of this study are available from the corresponding author upon reasonable request.

\section{Reference}

Han YL, Chen LZ. Mechanical Model of Domestic Gas Explosion Load [J]. Transactions of TianJin University, 2008, 14(6):434-440.

Kobiera A, Kindracki J, Zydak P, et al. A New Phenomenological Model of Gas Explosion Based on Characteristics of Flame Surface [J]. Journal of Loss Prevention in the Process Industries, 2007, 20 (3):271-280.

Molkov V, Dobashi R, Suzuki M, et al. Venting of deflagrations: Hydrocarbon-air and hydrogen-air systems[J]. Journal of Loss Prevention in the Process Industries, 2000, 13(3):397-409.

Mander JB, Priestley MJN, Park R. Theoretical stress-strain model of confined concrete[J] Journal of Structure Engineering, ASCE, 1988, 8: 1804-1 826 .

Ambrosini D, Luccioni B , Jacinto A, et al. Location and mass of explosive from structural 
damage[J]. Engineering Structures, 2005, 27(2):167-176.

Molkov V, Dobashi R, Suzuki M, et al. Modeling of vented hydrogen-air deflagrations and correlations for vent sizing [J]. Journal of Loss Prevention in the Process Industries, 1999, 12(2):147-156.

Murray J S, Vincent H Y T, Brian C. Analysis of results from large scale hydrocarbon gas explosions [J]. Journal of Loss Prevention in the Process Industries, 2000, (13):167-173.

Kumar R K, Dewit W A, Greig D R. Vented explosions of hydrogen-air mixtures in a large volume [J]. Combusion Science and Technology, 1989,66:251-266.

Kobiera A, Kindracki J , Zydak P, et al. A new phenomenological model of gas explosion based on characteristics of flame surface[J]. Journal of Loss Prevention in the Process Industries, 2007, 20(3):271-280.

Krauthammer T , Asce A M . Shallow-Buried RC Box-Type Structures[J]. Journal of Structural Engineering, 1984.

Krauthammer T , Bazeos N , Holmquist T J . Modified SDOF Analysis of RC Box-Type Structures[J]. Journal of Structural Engineering, 1986, 112(4).

Molkov V, Dobashi R, Suzuki M et al. Modeling of vented hydrogen-air deflagrations and correlations for vent sizing[J]. Journal of Loss Prevention in the Process Industries, 1999,12(2):147-156.

Oswald C J . Prediction of Injuries to Building Occupants From Column Failure and Progressive Collapse With the Bicads Computer Program[C]// Structures Congress. 2005. 